\title{
The Exchange Processes in the Patos Lagoon Estuarine Channel, Brazil
}

\author{
Wilian Correa Marques ${ }^{1 *}$, Igor Oliveira Monteiro ${ }^{2}$, Osmar Olinto Möller ${ }^{2}$ \\ ${ }^{1}$ Instituto de Matemática, Estatística e Física, Universidade Federal do Rio Grande, Rio Grande do Sul, Brasil \\ ${ }^{2}$ Instituto de Oceanografia, Universidade Federal do Rio Grande, Rio Grande do Sul, Brasil \\ E-mail: ${ }^{*}$ wilian_marques@yahoo.com.br \\ Received June 1, 2011; revised July 12, 2011; accepted August 4, 2011
}

\begin{abstract}
Investigation of process controlling the estuarine-shelf interaction in the Patos Lagoon estuarine channel is accessed using a two-dimensional numerical model. Results obtained suggest this approximation provides good precision level to investigate the advective transport of oceanic waters near the estuarine mouth. The introduction of coastal waters in synoptic time scales is dominated by advection in sub-superficial layers. This process results from the competition between flood currents driven by remote wind effects and gravitational circulation controlled by the intensity of the freshwater discharge. The short term exchange processes follow one most energetic cycle of 8 days and intense flood events occur during periods of low continental discharge and higher intensity winds. Very stratified salinity profiles are found during periods of moderated freshwater discharge. The salt transport is inversely related to the freshwater discharge intensity. It presents a mean rate of the $105 \mathrm{~kg} \cdot \mathrm{day}^{-1}$ transported landward during flood events.
\end{abstract}

Keywords: Freshwater Discharge, Stratification, Advection, Barotropic Oscillations

\section{Introduction}

During the last centuries the population has distributed along the coastal regions using the environment to live, work and to recreational activities. The population growth along these regions normally cause modifications in the river discharge and circulation patterns influencing the spill of toxic substances, nutrients and suspended sediments. Among the important coastal sites there are the costal lagoons occupying more than $13 \%$ of the coastal regions of the world [1]. One important hydrologic resource of the South America, the Patos Lagoon, is a coastal lagoon situated in the southern part of Brazil. Several studies have investigated the contributions of the wind effects and the freshwater discharge in synoptic time scales [2-8, among others]. These studies highlighted the physical mechanism controlling the hydrodynamic process and salinity pattern along the estuarine region. The exportation of continental waters via Patos Lagoon channel contributes to high primary and secondary production along the adjacent continental shelf [9]. This contribution influence directly the biologic dynamics of this region considered one the most important fishing zones of the Brazilian coast [10]. According to Ciotti et al. [11], the freshwater discharge pattern enhances the phytoplankton biomass in this region, where annual mean rates of primary production of around $160 \mathrm{~g} \mathrm{Cm}-2$ year-1 was observed by Odebrecht and Garcia [12]. The knowledge of the process controlling the estuarine-shelf interaction is fundamental to manage correctly this coastal environment and their adjacencies. In this way, the objective of this paper is develop a numerical model to estimate the salinity concentration near the Patos Lagoon mouth, based in current velocity measurements, giving an insight to the investigation of the exchange processes and salt mass transportation.

\subsection{Description of the Study Area}

The Patos Lagoon is a choked coastal lagoon located in the southern part of Brazil, between $30^{\circ}-32^{\circ} \mathrm{S}$ latitude and $50^{\circ}-52^{\circ} \mathrm{W}$ longitude (Figure 1). The estuarine region covers $10 \%$ of their total area [13]. The principal rivers contributing in the north of the lagoon present a discharge pattern of temperate regions influenced in interannual and inter-decadal timescales for processes of climatic order [14]. The wind action is the most effective forcing of the Patos Lagoon circulation in synoptic Time- 


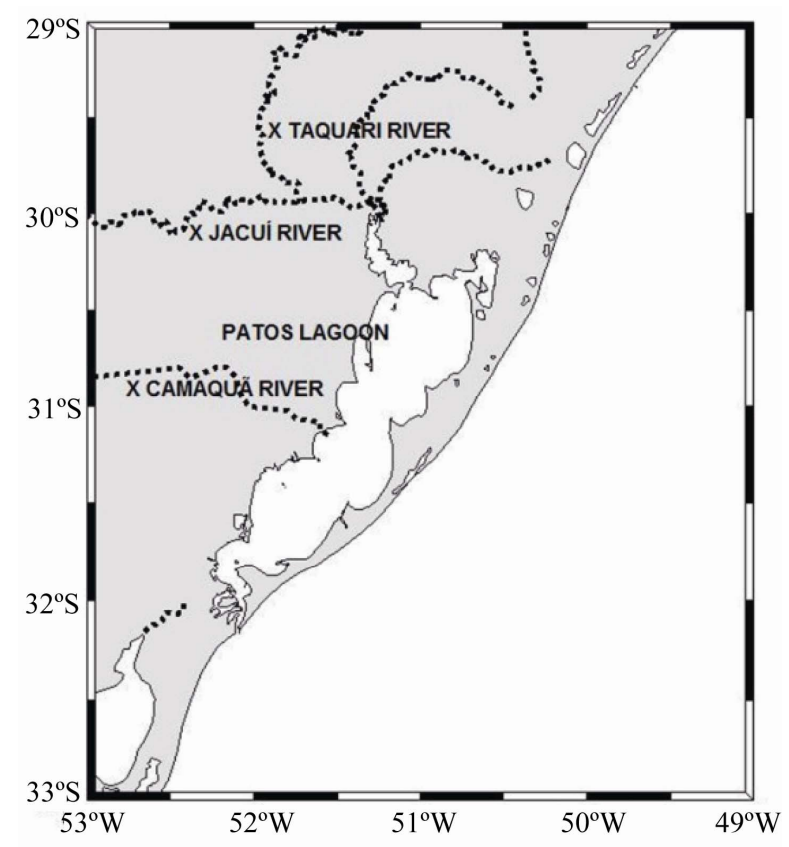

(a)

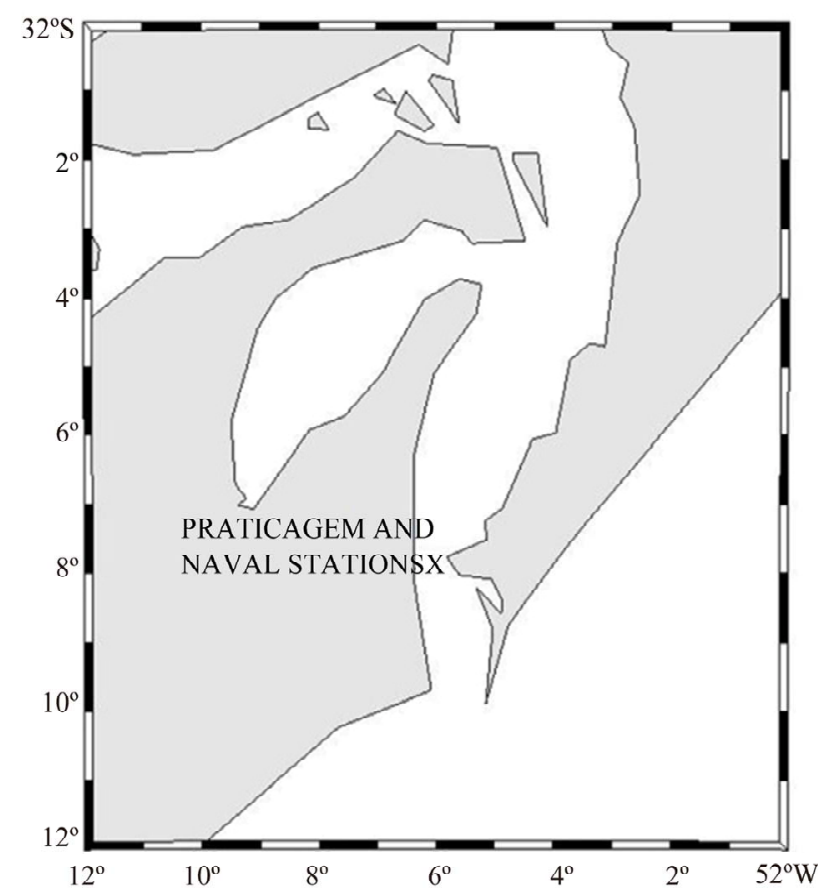

(b)

Figure 1. Patos Lagoon, their principal rivers and the measurement stations.

scales [5]. The combination of the local and remote wind action is the principal mechanism to introduce salt into the estuarine region $[2,3,5]$. The tides are mixed, with diurnal dominance, and their effects are restricted to the coastal zone and the estuarine region of the Patos Lagoon [5].

\section{Methodology}

The study is based in development of a numerical model and signal analysis. In this study were used hourly data sets of current velocity and salinity obtained near the Patos Lagoon entrance (Figure 1) during different periods. The salinity and velocity data sets used in the model calibration were obtained with thermo-salinometers and current sensors, respectively. These data were collected near the Praticagem pilot station of Rio Grande at $1 \mathrm{~m}$ and $10 \mathrm{~m}$ depth, from August 2th to August 9th 1999. The salinity data sets used to validate the model were obtained with thermo-salinometers near the Rio Grande Naval station at $1 \mathrm{~m}$ and $10 \mathrm{~m}$ depth, from April 29th to May 31st 2004. The current velocity data used to force the model in the validation experiment were obtained near the Praticagem pilot station of Rio Grande with a vertical profiler ADCP (Acoustic Doppler Current Profiler) between April 29th and May 31th 2004. This sensor collected current velocity considering 15 vertical levels through the $15 \mathrm{~m}$ depth water column. The case study was performed using current velocity obtained with the same profiler ADCP near the Praticagem station, from August 17th 2005 to January 31st 2007, to force the model and calculate the salinity time series in different points of the water column.

Time series of wind and freshwater discharge were used to aid in result analyzes. According to Marques [15], the Taquari and Jacuí rivers (tributaries of the Guaíba river) and the Camaquã river (Figure 1(a)) are the principal tributaries of the Patos Lagoon. The river discharge data are provided by the Brazilian National Water Agency (www.ana.gov.br, ANA) and the time series ranges between August 17th 2005 and December 31st 2006. Time series of winds from August 17th 2005 to January 31st 2007 was obtained from reanalysis project (National Oceanic \& Atmospheric Administration-NOAA, www. cdc. noaa.gov/cdc/reanalysis) near the Praticagem pilot station. Table 1 presents the data sets used in this study.

The results obtained with the numerical model were used to access the spatial and temporal variability of the power in salinity and velocity near the Patos Lagoon mouth using wavelet analyses. The spectral content of the velocity and salinity time series were analyzed using an adaptation of the Morlet wavelet method described by Torrence and Compo [16]. The spatial and temporal variability of the velocity and salinity data series were accessed by scale-averaging the wavelet power spectra at multiple locations [16]. The cross-wavelet spectrum was performed according to Torrence and Compo [16], in order to verify the covariance between the most energetic events observed in the salinity and velocity wavelet power spectrum. 
Table 1. Data sets and periods used in the study.

\begin{tabular}{|c|c|c|}
\hline Experiments & Data & Period \\
\hline Calibration & $\begin{array}{l}\text { Salinity and } \\
\text { velocity }\end{array}$ & August $2^{\text {th }}$ to August $9^{\text {th }} 1999$ \\
\hline Validation & $\begin{array}{l}\text { Salinity and } \\
\text { velocity }\end{array}$ & April $29^{\text {th }}$ and May $31^{\text {st }} 2004$ \\
\hline Case study & Velocity & $\begin{array}{l}\text { August } 17^{\text {th }} 2005 \text { to January } \\
31^{\text {st }} 2007\end{array}$ \\
\hline Case study & River Discharge & $\begin{array}{l}\text { August } 17^{\text {th }} 2005 \text { to December } \\
31^{\text {st }} 2006\end{array}$ \\
\hline Case study & Winds & $\begin{array}{l}\text { August } 17^{\text {th }} 2005 \text { to January } \\
31^{\text {st }} 2007\end{array}$ \\
\hline
\end{tabular}

In order to obtain an estimation of the salt flux through the Patos Lagoon estuarine channel was used the approximation described by Smith [17] to calculate the instantaneous advective salt transport with one-dimensional flow as:

$$
T_{a}=\int_{A} v s \mathrm{~d} A
$$

where: $T_{a}$ is the transport integrated over the cross section, $v$ is the longitudinal component of velocity, $s$ is the salinity concentration, and $A$ the cross section area. In the calculations were used the 15 vertical levels of velocity, calculated salinity and the cross section area estimated using topographical charts.

\subsection{The Numerical Model}

To accomplish the objectives of this study was developed a two-dimensional numerical model based in the transport equation of dissolved matter in the sea water as:

$$
\frac{\partial T}{\partial t}+\boldsymbol{u} \cdot \boldsymbol{\nabla}(T)=v_{T} \nabla^{2}(T)
$$

Where: $T$ represents an arbitrary concentration of dissolved tracer $\left(\mathrm{mg} \cdot \mathrm{L}^{-1}\right), u$ is the velocity vector $\left(\mathrm{m} \cdot \mathrm{s}^{-1}\right)$ and $v_{T}$ the diffusion coefficient $\left(\mathrm{m}^{2} \cdot \mathrm{s}^{-1}\right)$. The equation is solved using finite difference methods. The TVD scheme (Total Variance Diminishing) is applied to discretize the advective part of the equation $[18,19]$. This method mounts a first order scheme adding anti-diffusive fluxes assuring the minimization of the total variance. The base of this scheme follows the Lax-Wendroff scheme described by Kanta and Clayson [20]. The discretization of the parabolic part of the system represented by the diffusive term is obtained using the Forward-Time Centered Space (FTCS) method. This method is an explicit and first order scheme in time and second order in space [20].

The model considered is two-dimensional and the domain covers the region between the Patos Lagoon mouth and the Praticagem pilot station (Figure 2(a)). The numerical domain considered 100 elements with equal sizes of $200 \mathrm{~m}$. The domain considers a constant water depth of $16 \mathrm{~m}$, with 15 vertical levels equally spaced at each $1 \mathrm{~m}$ depth. The model ran with $60 \mathrm{~s}$ time step and it was forced only using the longitudinal component of the current velocity (north-south component) because of the channel orientation. The diffusion coefficient is considered constant in time and the boundary condition of the model considers null salinity in the north boundary and 34 in the south boundary. The initial condition considered is a variation curve of the salinity as a function of the position along the domain (Figure 2(b)).

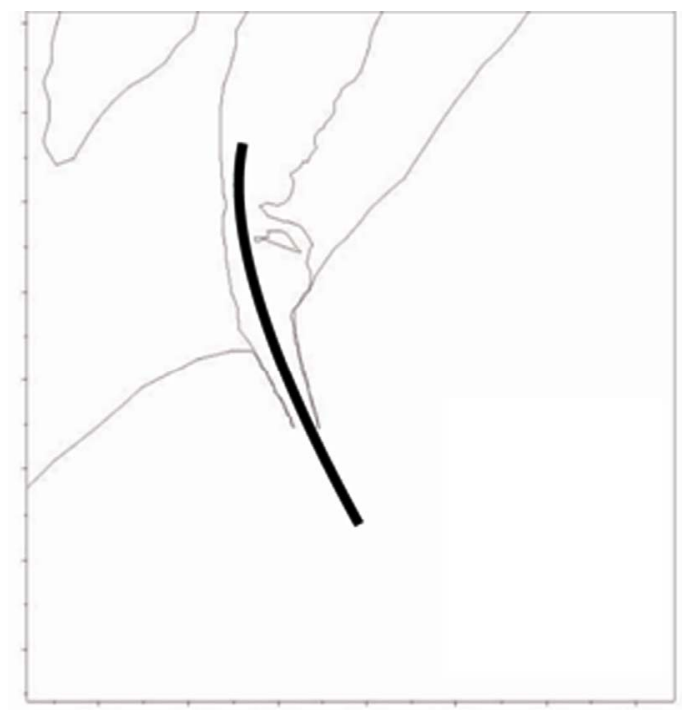

(a)

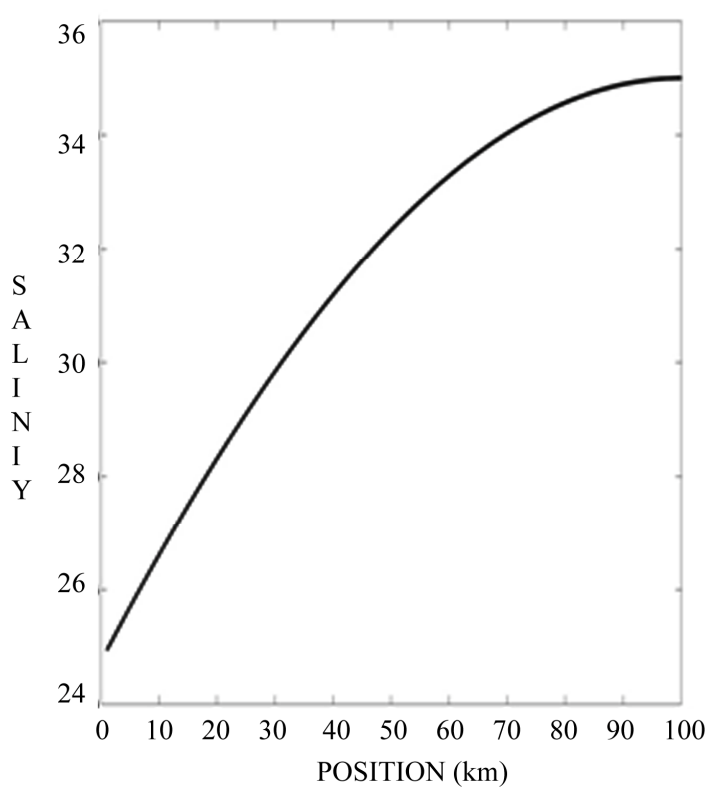

(b)

Figure 2. Model domain (a) and initial condition of salinity as a function of position along the domain (b). 


\subsection{The Model Calibration-1999 Year}

The calibration test consisted in analyze the influence of the horizontal diffusion coefficients. The model was forced with the longitudinal component of the current velocity measured at $1 \mathrm{~m}$ and $10 \mathrm{~m}$ depth. The salinity time series calculated was compared with the measurements between August $2^{\text {th }}$ and August $9^{\text {th }} 1999$. The results (Figure 3) indicate that lower diffusion coefficients (1 and $10 \mathrm{~m}^{2} \cdot \mathrm{s}^{-1}$ ) underestimate the mixing process giving the purely advective character to the salinity time series. The better results were obtained using a diffusion coefficient of $100 \mathrm{~m}^{2} \cdot \mathrm{s}^{-1}$ (Figure 3(a) and (b)) where the minimal values of salinity associated to ebb flow periods (bottom series) are better represented. Fernandes et al. [8] using the hydrodynamic model TELEMAC3D to study the Patos Lagoon estuary observed best results of the model calibration using diffusion coefficients between 10 e $100 \mathrm{~m}^{2} \cdot \mathrm{s}^{-1}$.

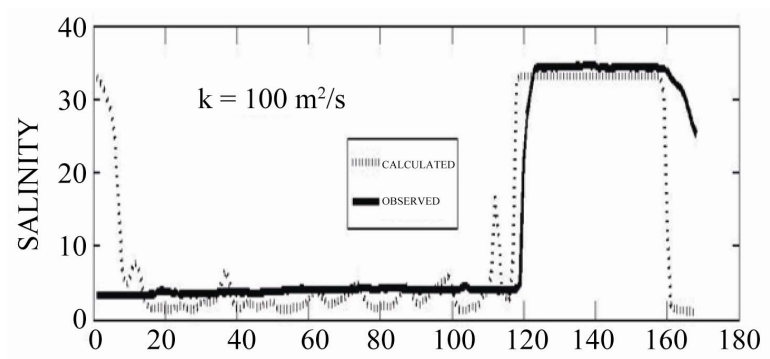

(a)

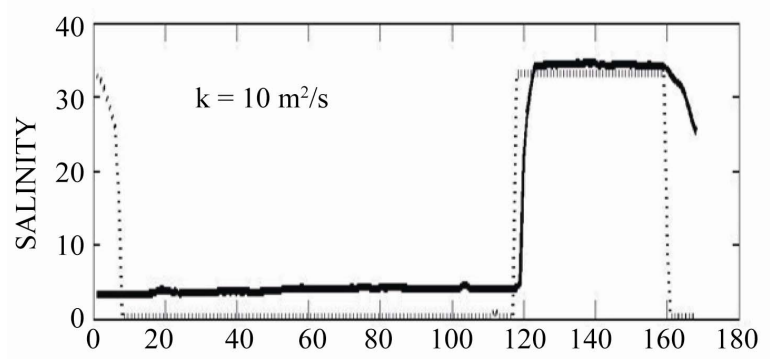

(c)

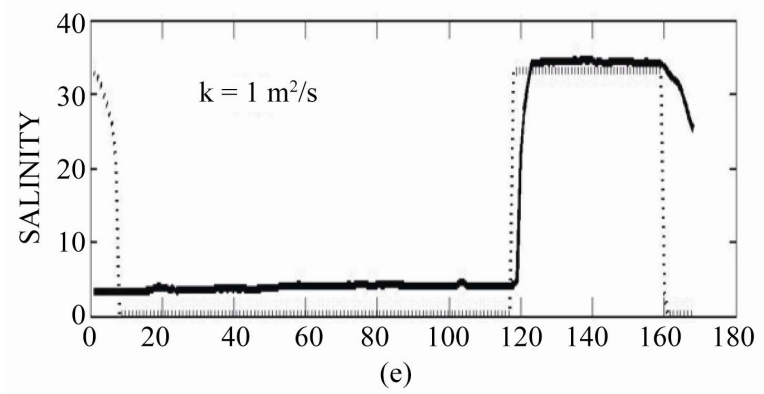

TIME (hours)

\subsection{The Model Validation - 2004 Year}

The validation test was performed between April $29^{\text {th }}$ and July $4^{\text {th }} 2004$ using horizontal diffusion coefficient of the $100 \mathrm{~m}^{2} \cdot \mathrm{s}^{-1}$. The model was used to calculate the salinity time series at $1 \mathrm{~m}$ and $10 \mathrm{~m}$ depth near the Praticagem pilot station of Rio Grande using time series of current velocity.

The results presented (Figure 4) indicate that the simplified model can reproduce satisfactorily the salinity pattern observed near the entrance of the Patos Lagoon channel. In order to quantify the reproducibility of the model, the method proposed by Walstra et al. [21] was used. This method calculates the Root Mean Square Absolute Error (RMAE) between measured and calculated time series, and according to Wasltra et al. [21], values lower than 0.4 indicate good reproduction of the numerical model. The calculated RMAE during this period indicate values around 0.33 in the surface and 0.24 near the bottom.

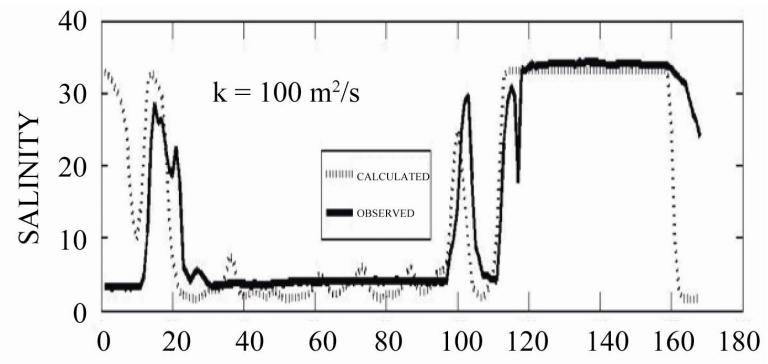

(b)

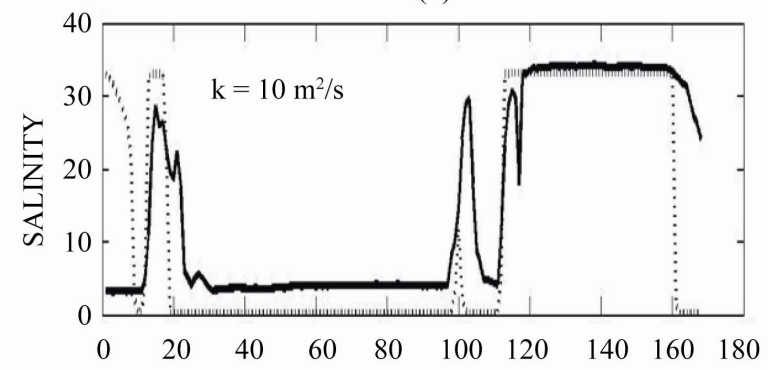

(d)

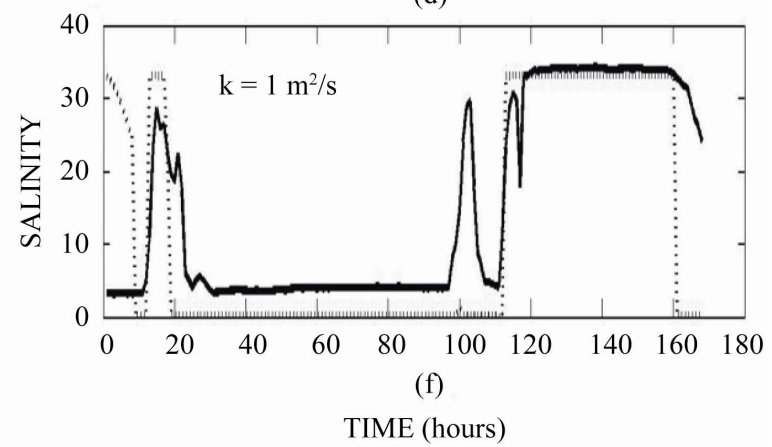

Figure 3. Calculated and observed salinity time series considering horizontal diffusion coefficients of the $100 \mathrm{~m}^{2} \cdot \mathrm{s}^{-1}$ to surface (a) and bottom (b); of the $10 \mathrm{~m}^{2} \cdot \mathrm{s}^{-1}$ to surface (c) and bottom (d) and, of the $1 \mathrm{~m}^{2} \cdot \mathrm{s}^{-1}$ to surface (e) and bottom (f) between August $2^{\text {th }}$ and August $9^{\text {th }} 1999$. 


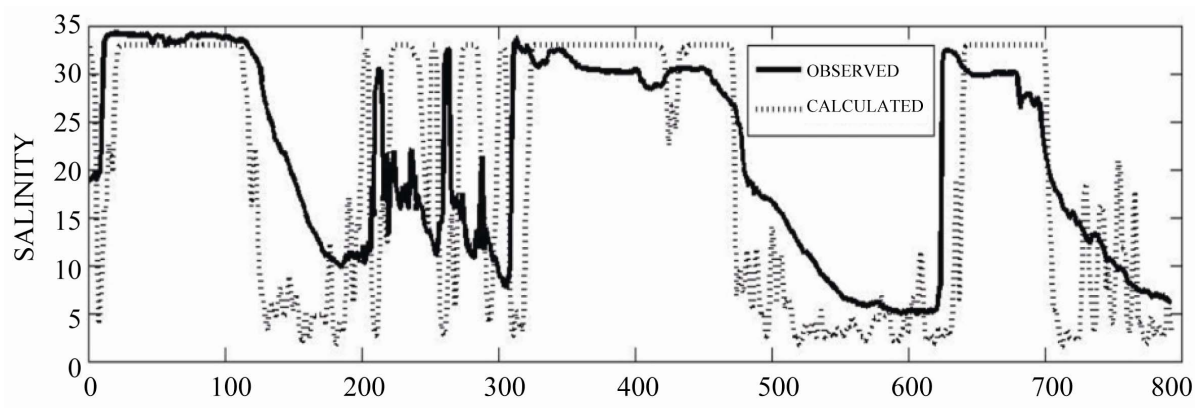

(a)

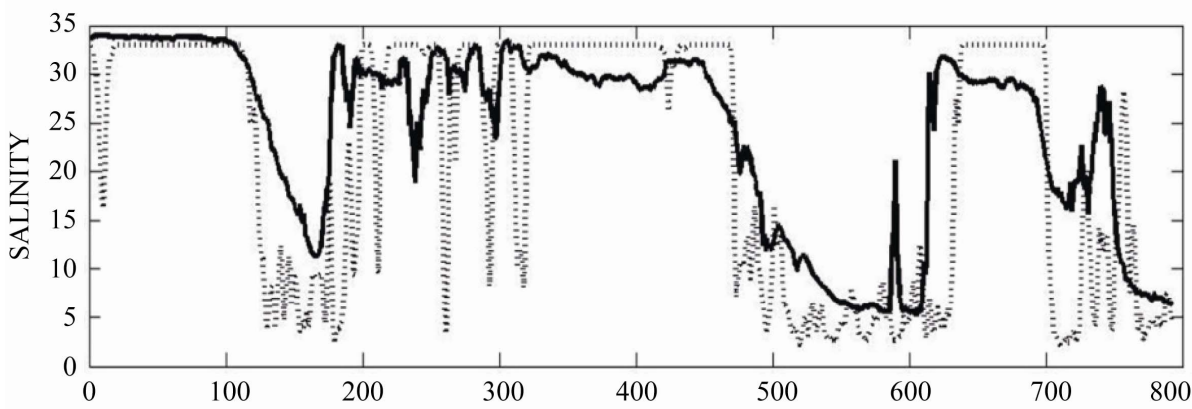

(b)

TIME (hours)

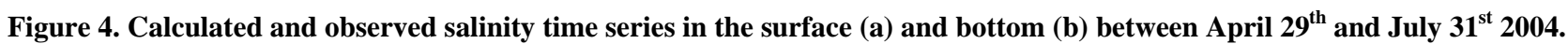

\section{Results}

The numerical model was used to calculate the salinity near the Patos Lagoon mouth considering the horizontal diffusion parameter of the $100 \mathrm{~m}^{2} \cdot \mathrm{s}^{-1}$. The velocity time series along the 15 vertical levels are presented as time/ depth profile (Figure 5(a)). The positive values (clearest values) are associated to flood events along the estuarine channel while the (grayest values) are associated to ebb events. The time evolution of the velocity indicates the intermittent ebb/flood pattern associated to the north/ south quadrant winds influence (Figure 6(a)). The ebbing events are intensified during periods of higher and moderate freshwater discharge conditions (Figure 6(b)) occurring from austral winter to austral spring. The calculated salinity time/depth profile (Figure 5(b)) indicates the influence of ebb/flood periods with lowest/highest Salinity values, respectively. During 533 days of simulation, salinity profiles going from well mixed to very stratified conditions can be found in this point of the Patos Lagoon channel. Homogeneous salinity profiles following intense ebb conditions are observed during the first 100 days (Figure 5(b)). During this period, the combination of dominant north quadrant winds and highest freshwater discharge contributes to the intense ebb flows. Very stratified periods are observed, from 250 to 450 days, being performed by south quadrant winds and moderate freshwater discharge. The weakly stratified periods occur intermittently from 100 to 250 days during lowest discharge periods. During this period, the influence of the wind effects is most important controlling the exchange process (Figures 5(a) and (b)).

The spectral content of the velocity and salinity time series at 2 and $14 \mathrm{~m}$ depth were investigated using wavelet analysis. This method allowed locating power variations within a discrete time series in a range of scales providing the local and the global power spectrum. Analysis of the local power spectrum (Figures 7(a) and (b), Figures 8(a) and (b)) indicates that physical process lower than 16 days are the principal mechanism controlling the longitudinal component of velocity and the advection of oceanic water through the estuarine channel. These processes occur intermittently during the whole study period.

Some differences are found in the local power spectrum of surface and bottom layers (Figures 7(a) and (b), Figures 8(a) and (b)) with respect to the energetic levels, occurrence of events and their influence through the water column. The global power spectrum of salinity and velocity (Figures 7(c) and (d), Figures 8(c) and (d)) corroborate this point of view indicating bottom energetic levels at least 3 times greater than superficial ones. These results suggest the dominance of remote wind effects controlling the exchange process.

The scale-averaging wavelet power spectrum at each position along the water depth was computed using the 


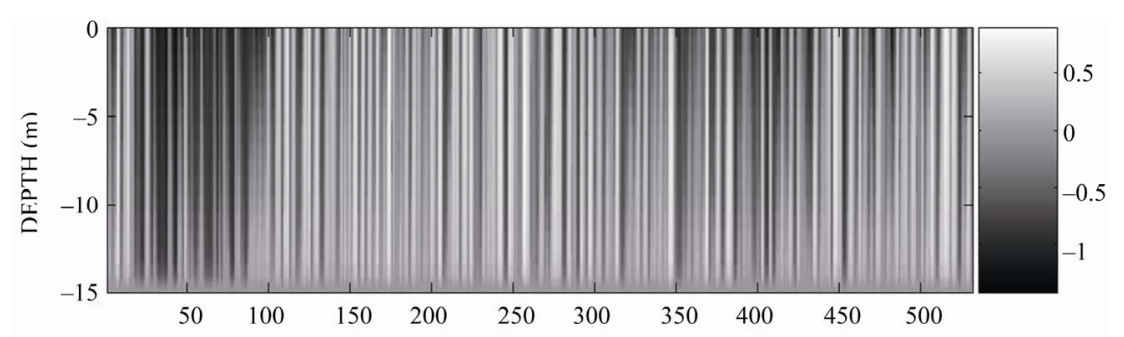

(a)

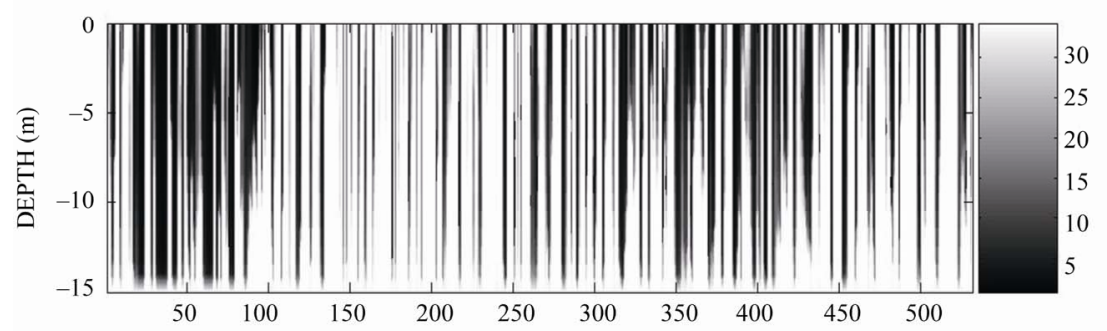

(b)

TIME (days)

Figure 5. Time/depth profile of the observed velocity (a) and calculated time/depth profile of salinity (b) from August $17^{\text {th }}$ 2005 to January $31^{\text {st }} 2007$.
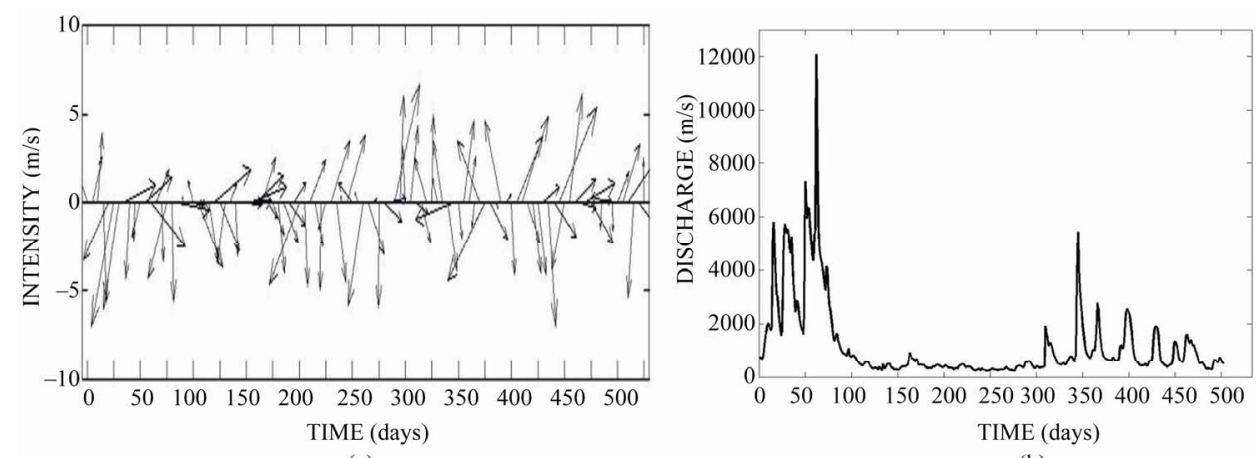

(a)

(b)

Figure 6. Wind time series (a) and river discharge (b) time series from August 17 2005 to January $31^{\text {st }} 2007$.
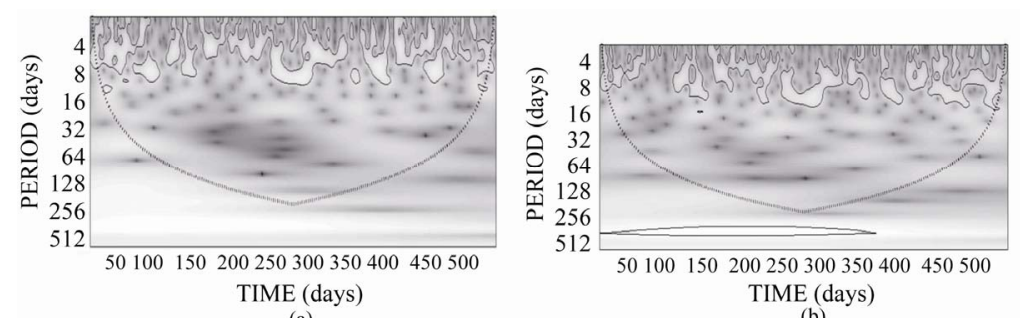

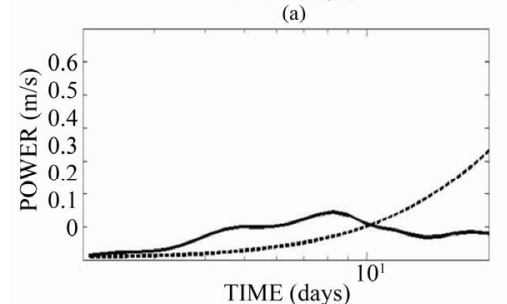

(c)

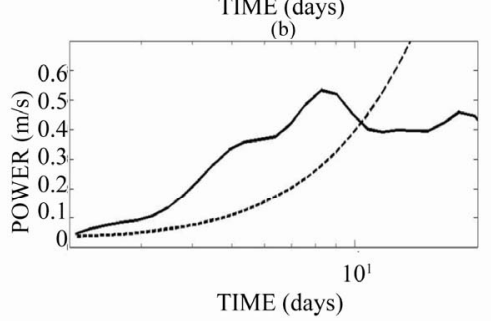

(d)

Figure 7. Wavelet power spectrum of velocity time series at $2 \mathrm{~m} \mathrm{(a)}$ and $14 \mathrm{~m} \mathrm{(b)} \mathrm{depth.} \mathrm{The} \mathrm{dashed} \mathrm{line} \mathrm{indicates} \mathrm{the} \mathrm{cone} \mathrm{of}$ influence, below which edge effects become important and the solid contour is the $95 \%$ confidence level. Global wavelet spectrum of the velocity time series at $2 \mathrm{~m}$ (c) and $14 \mathrm{~m}$ (d) depth. The dashed line indicates the $95 \%$ confidence level. 


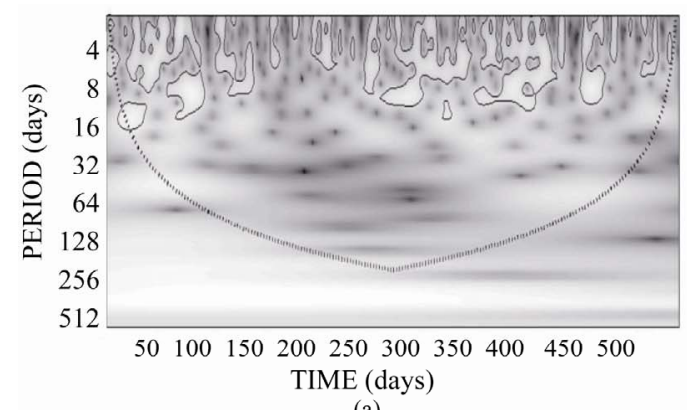

(a)

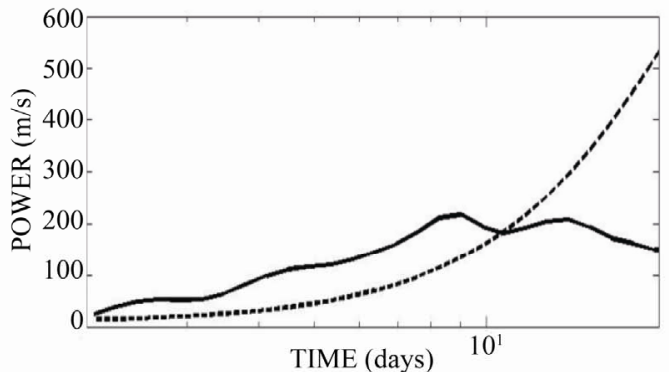

(c)

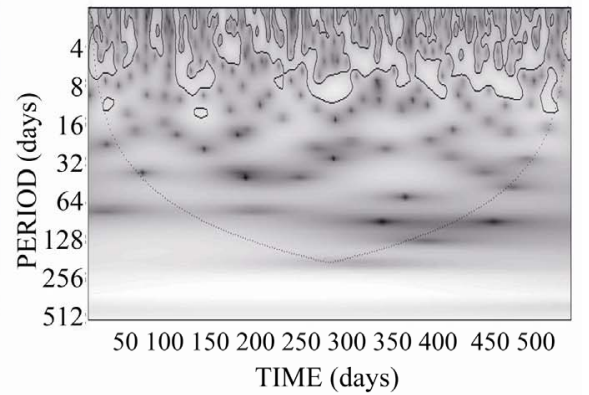

(b)

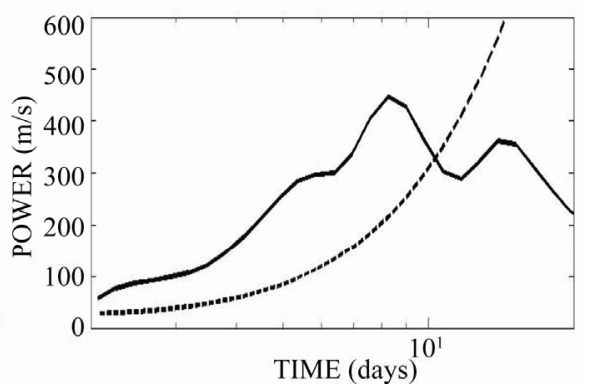

(d)

Figure 8. Wavelet power spectrum of the salinity time series at $2 \mathrm{~m}$ (a) and $14 \mathrm{~m}$ (b) depth. The dashed line indicates the cone of influence, below which edge effects become important and the solid contour is the $95 \%$ confidence level. Global wavelet spectrum of the salinity time series at $2 \mathrm{~m}$ (c) and $14 \mathrm{~m}$ (d) depth. The dashed line indicates the $95 \%$ confidence level.

Morlet wavelet scale-averaged over the 1 - 20 days band.

The time averaged power spectra of the velocity and salinity time series as a function of the water depth (Figures 9(a) and (b)) indicates high energy with 95\% confidence extending along the water depth during some periods.

The high energy events observed in these wavelet spectra indicate the introduction of oceanic waters through the Patos Lagoon estuarine channel via sub-superficial layers. During some periods, principally from 250 and 500 days, the competition between flood conditions driven by south quadrant wind effects and ebb flows associated to the moderate freshwater discharge induces vertical stratification. However, the most energetic events occur during periods of most intense south quadrant winds and low discharge conditions performing well mixed salinity profiles.

The cross-wavelet spectrum (not shown) indicated large covariance between the time series at all scales from 1 to 20 days. The depth averaged time series from the cross spectral analysis (Figure 10(a)) indicates the tendency of increasing variance to the end of period. The less energetic period is observed during the first 100 days because the dominance of ebb conditions driven by the most intense freshwater discharge. Between 100 and 250 days, the discharge is less intense but there are few events of south quadrant winds. The variance increases from 250 days to the end of period because of the occurrence of very stratified and well mixed conditions. The high ener- getic events observed (Figure 10(a)) occur during periods of intense salt pumping through the estuarine channel characterizing vertical well mixed conditions. The time averaged profile of the cross spectral analysis (Figure 9(b)) suggests that introduction of oceanic waters occurs normally below $3 \mathrm{~m}$ depth.

The integrated mass transport time series (Figure 11) suggests a pattern of salt transport through the estuarine channel inversely related to the freshwater intensity, corroborating the wavelet analysis. During the first 100 days (austral winter and spring), the high intensity of freshwater discharge hinders the transport landward and the ebb events are dominant over the flood ones, therefore, periods of null salt transport are observed. From 100 to 300 days (austral summer and fall), the landward transport is most intensive reaching values of $250 \mathrm{~kg} \cdot \mathrm{day}^{-1}$ because of the lower freshwater discharge. The last 200 days present a similar pattern with lower salt transport during moderate freshwater discharge periods and intense salt transport when the freshwater discharge decreases. The high energetic events observed through the cross-spectrum analysis (Figure 9(a)) are associated to longer periods of landward salt transportation (Figure 11).

\section{Discussion}

The investigation of process controlling the estuarineshelf interaction is fundamental to develop correct management strategies of the coastal environment and their 


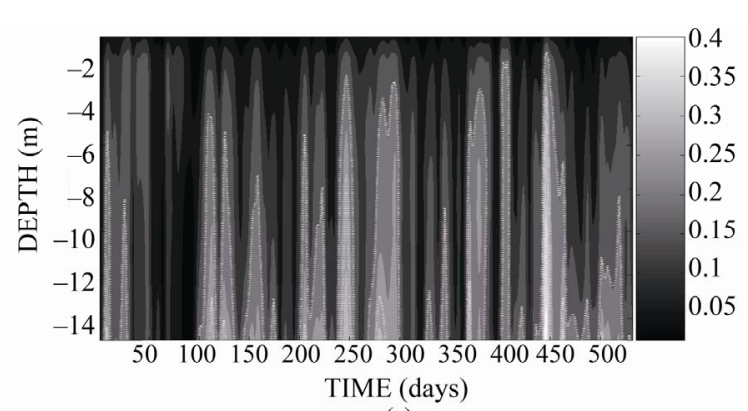

(a)

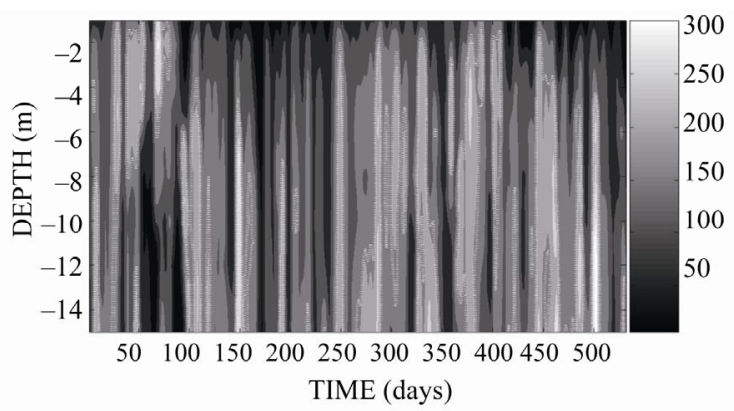

(b)

Figure 9. The time averaged power spectra of the velocity (a) and salinity (b) time series as a function of the water depth. The thick white contour is the $95 \%$ confidence level.

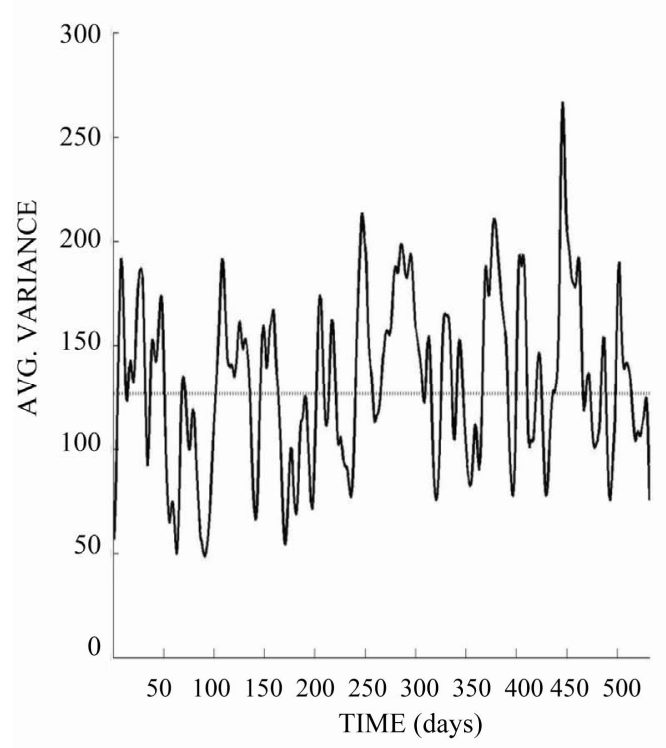

(a)

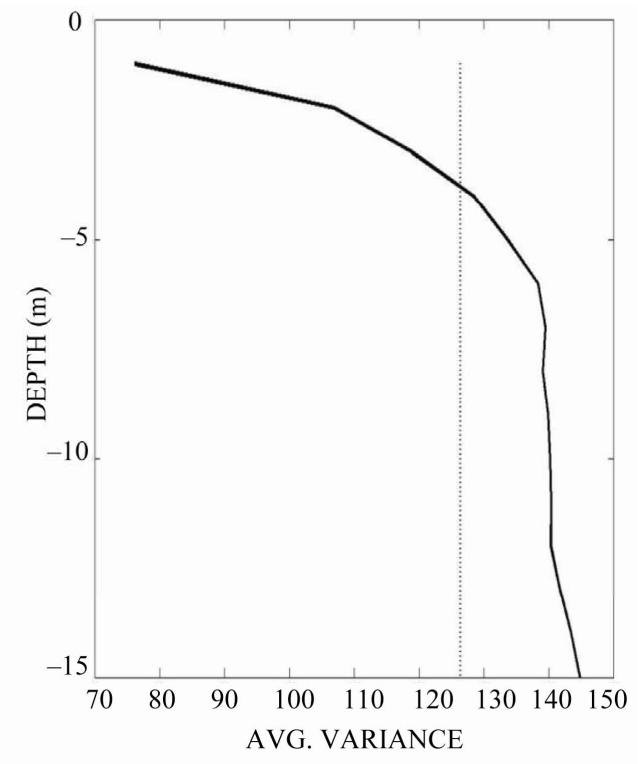

(b)

Figure 10. Time series of scale average variance from cross spectral analysis over all depths (a) and scale average variance from cross spectral analysis over all times (b). The dashed line indicates the $95 \%$ confidence level from the cross spectral analysis.

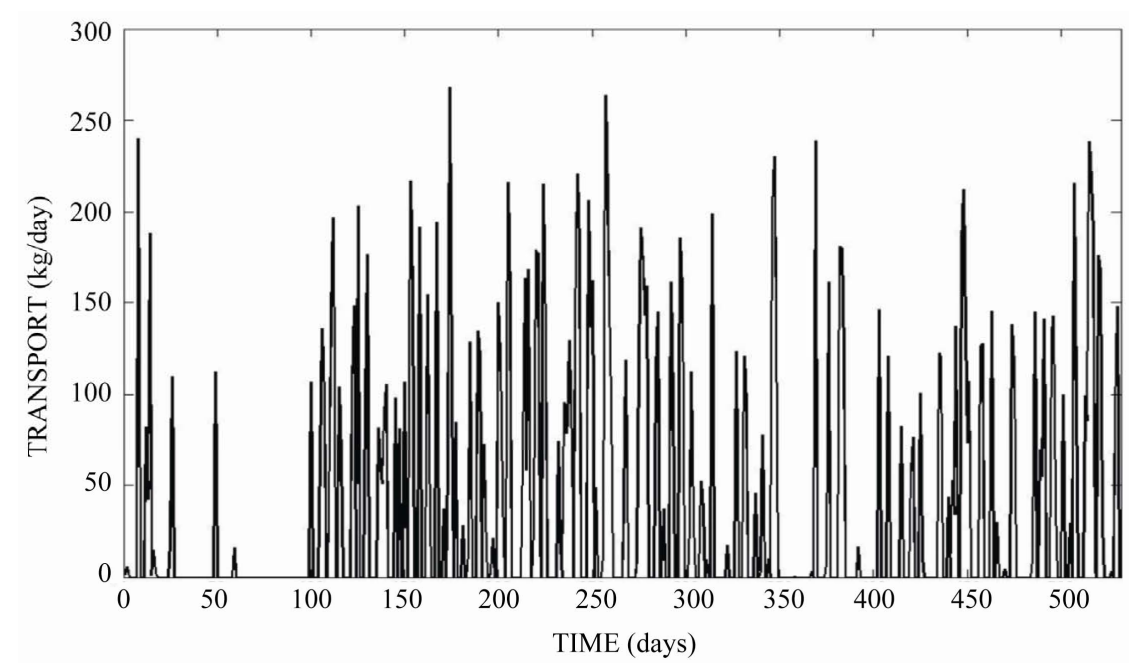

Figure 11. Calculated time series of salt transport near the Patos Lagoon estuarine channel. 
adjacencies. The salt plays an important role in determining the estuarine characteristics serving as a natural tracer and supporting different applications. According to Smith [17], the energetic balance of a coastal lagoon depends principally of the access channel configuration controlling the exchange rates of materials, residence time and water quality. The development of simplified numerical models to understand the physical process occurring in these regions is attractive, because of the low computational cost compared with complex modeling systems. The high costs associated to obtaining of direct measurements are other important difficulty involving the monitoring of the estuarine-shelf process. In this sense, this paper suggests the use of two-dimensional numerical model to investigate the salinity behavior, in time and through the water depth, near the Patos Lagoon estuarine mouth. The results obtained are satisfactory according to the calibration and validation experiments, and considering that their application involved a very low computational cost. This model is applied to study salinity patterns, but, this approximation could be used to any conservative dissolved substance present in coastal waters in same way.

The results of the calculated salinity along the water depth are compatible with the velocity pattern measured in situ. The salinity variations near the estuarine mouth ranged from 0 to 34 and the main vertical salinity structures described by Cameron and Pritchard [22] were observed during the study period. Very stratified conditions occurred during periods of moderate continental discharge (austral winter and austral spring) taking place during several days. Hartmann and Schettini [2], and Möller and Castaing [23] analyzing field data sets observed similar conditions occurring along the whole estuarine region. The introduction of coastal waters through the estuarine channel is dominated by advection through the sub-superficial layers. This process results from the competition between flood currents driven by remote wind effects and the gravitational circulation modulated by the intensity of the freshwater discharge. These results corroborate the previous studies done by Möller et al. [5], Castelão and Möller [24], Fernandes et al. [8]. These authors have demonstrated the combination of local and remote wind action controlling the exchange process between the Patos Lagoon and adjacent coast, during low river discharge conditions, in synoptic time scales from 3 to 17 days.

The physical mechanisms responsible to maintain the exchange process in synoptic time scales from $17^{\text {th }} \mathrm{Au}-$ gust 2005 to $31^{\text {st }}$ January 2007 followed cycles from 1 to 10 days. The most energetic cycle (8 days band) indicates the dominant timescale associated to the short term exchange process coincident to the frontal system pas- sage over the study region. The frontal systems passage in this region is associated to the south quadrant winds, and the resultant Ekman transport along the adjacent continental shelf induces the propagation of barotropic oscillations transporting oceanic waters landward. The wind acts an important forcing mechanism of the estuarine circulation [25] and the far field wind plays as important mechanism controlling the water exchange with the continental shelf [26].

The freshwater discharge is important to perform vertical stratification along the Patos Lagoon estuarine region during periods of moderate intensity, and to prevent the introduction of coastal waters during high intensity periods. Marques et al. [27] verified that the intensity of the river discharge at the northern boundary of the Patos Lagoon controls the ebb conditions (93\% of the variance) in the mouth of the estuary. These authors verified that longer periods of ebb flow higher than $2000 \mathrm{~m}^{3} \cdot \mathrm{s}^{-1}$ can prevent the wind action hindering the introduction of marine waters on the south part of the estuarine region. The most energetic flood events near the estuarine mouth occur during periods from low to moderate continental discharge and higher intensity winds. These events are characterized by longer periods of flood conditions contributing to higher salt input through the estuarine channel. The salt transport through the estuarine channel occurs in sub-superficial layers (below $3 \mathrm{~m}$ depth) being inversely related to the intensity of the freshwater discharge. In this way, it follows a seasonal pattern and the integration of the salt transport time series during the study period suggests a mean rate of the $105 \mathrm{~kg} \cdot \mathrm{day}^{-1}$ transported landward through the Patos Lagoon estuarine channel during flood events.

\section{Conclusions}

The analysis of the exchange process trough the Patos Lagoon estuarine channel from $17^{\text {th }}$ August 2005 to $31^{\text {st }}$ January 2007 considering observed velocity fields and calculated salinity indicates that:

1) The exchange-process near the estuary mouth can be investigated using a two-dimensional approximation with good precision level, but the principal process controlling the introduction of oceanic waters, in synoptic time scales, is the advection along that channel.

2) The introduction of oceanic waters through the estuarine channel is dominated by advection through the sub-superficial layers. This process results from the competition between the flood currents driven by remote wind effects (barotropic oscillations) and gravitational circulation controlled by freshwater discharge. The barotropic oscillations forced by the frontal system passage over the adjacent coastal region follows a dominant time 
scale of 8 days.

3) Freshwater discharge is important to create vertical stratification during periods of moderate intensity, and to hinder the introduction of coastal waters during high intensity periods (normally from austral winter to spring). The most energetic flood events occur during periods of low continental discharge and higher intensity winds.

4) The salt transport through the estuarine channel follows a seasonal pattern modulated by the intensity of freshwater discharge. The integrated transport indicates a mean rate of the $105 \mathrm{~kg} \cdot \mathrm{day}^{-1}$ advected landward during flood events.

\section{Acknowledgments}

The authors are grateful to the Fundação de Amparo à Pesquisa do Estado do Rio Grande do Sul (FAPERGS) for sponsoring this research under contract 1018144. Further acknowledgements go to the Brazilian National Water Agency (ANA) and the National Oceanic \& Atmospheric Administration (NOAA) for supplying the fluvial discharge and wind data sets, respectively to accomplish this research.

\section{References}

[1] B. Knoppers and B. Kjerfve, "Coastal Lagoons of SouthEastern Brazil: Physical and Biogeochemical Characte- ristics,” In: G. M. Perillo, M. C. Picollo and M. Pino- Quivira, Eds., Estuaries of South America-Their Dynamics and Geomorphology, Springer Verlag, Heidelberg, 1999, pp. 25-66.

[2] C. Hartmann and C. A. F. Schettini, "Aspectos Hidrológicos na Desembocadura da Laguna dos Patos, RS,” Revista Brasileira de Geociências, Vol. 21, No. 4, 1991, pp. 371-377.

[3] O. O. Möller, "Hydrodinamique de La Lagune dos Patos, Mésures et Modelisation,” DSc. Thesis, Université Bordeaux I, Bordeaux, 1996.

[4] O. O. Möller, J. A. Lorenzzetti, J. L. Stech and M. M. Mata, "The Patos Lagoon Summertime Circulation and Dynamics,” Coastal Shelf Research, Vol. 16, No. 3, 1996, pp. 335-351.

[5] O. O. Möller, P. Castaing, J. C. Salomon and P. Lazure. "The Influence of Local and Non-Local Forcing Effects on the Subtidal Circulation of Patos Lagoon,” Estuaries, Vol. 24, No. 2, 2001, pp. 297-311. doi:10.2307/1352953

[6] E. H. L. Fernandes, "Modelling the Hydrodynamics of the Patos Lagoon, Brazil,” DSc. Thesis, Institute of Marine Studies Faculty of Science, University of Plymouth, Plymouth, 2001.

[7] E. H. L. Fernandes, K. R. Dyer, O. O. Möller and L. F. H. Niencheski, “The Patos Lagoon Hydrodynamics during an El Niño Event (1998)," Continental Shelf Research, Vol. 22, No. 11-13, 2002, pp. 1699-1713. doi:10.1016/S0278-4343(02)00033-X
[8] E. H. L. Fernandes, K. R. Dyer and O. O. Möller, "Spatial Gradients in the Flow of Southern Patos Lagoon," Journal of Coastal Research, 2005, Vol. 20, pp. 102-112.

[9] P. C. Abreu, H. W. Granéli and C. Odebrecht, "Produção Fitoplanctônica e Bacteriana na Região da Pluma Estuarina da Lagoa dos Patos-RS, Brasil,” Atlântica, Rio Grande, Vol. 17, No. 1, 1995, pp. 35-52.

[10] J. Castello, A. Duarte, O. O. Möller, F. Niencheski, C. Odebredcht, G. Weiss, R. Habiaga, V. Bellotto, D. Kitzmann, C. Souto, R. Souza, A. Ciotti, G. Fillmann, P. Schwingell, J. Bersano, M. Cirano, K. Freire, I. Lima, R. Mello, A. Monteiro, C. Resgalla, I. Soares and M. Suzuki. "On the Importance of Coastal and Subantartic Waters for the Shelf Ecosystem off Rio Grande do Sul,” Anais do II Simpósio de Estrutura, Função e Manejo de Ecossistemas da Costa Sul e Sudeste, São Paulo-Brazil, I. Vol. 71, No. 1, 1990, pp. 112-129.

[11] A. M. Ciotti, C. Odebrecht, G. Fillmann and O. O. Möller, "Freshwater Outflow and Subtropical Convergence Influence on Phytoplankton Biomass on the Southern Brazilian Continental Shelf," Continental Shelf Research, Vol. 15, No. 14, 1995, pp. 1737-1756. doi:10.1016/0278-4343(94)00091-Z

[12] C. Odebrecht, and V. M. T. Garcia, “Pytoplankton,” In: U. Seeliger, C. Odebrecht and J. P. Castello, Eds., Subtropical Convergente Environments, the Coast and Sea in the Southwestern Atlantic, Springer-Verlag, Berlin, 1996.

[13] P. Delaney, "Fisiografia e Geologia de Superfície da Planície Costeira do Rio Grande do Sul,” Especial da escola de Geologia de Porto Alegre, Vol. 6, 1965, pp. 1-105.

[14] W. C. Marques and O. O. Möller, "Variabilidade Temporal em Longo Período Dadescarga Fluvial e Níveis de Água na Lagoa dos Patos, Rio Grande do Sul, Brasil," Revista Brasileira de Recursos Hídricos, Vol. 13, No. 3, 2008.

[15] W. C. Marques, "Padrões de Variabilidade Temporal nas Forçantes da Circulação e Seus Efeitos na Dinâmica da Lagoa dos Patos, Brasil,” Master's Thesis, University of Rio Grande, Rio Grande do Sul, 2005.

[16] C. Torrence and G. P. Compo, "A Practical Guido to Wavelet Analysis,” Bulletin of the American Meteorological Society, Vol. 79, No. 1, 1998, pp. 61-78.

[17] N. P. Smith, "Water, Salt and Heat Balance of Coastal Lagoons,” Elsevier Oceanography Studies, Vol. 60, 1994, pp. 69-101. doi:10.1016/S0422-9894(08)70009-6

[18] A. Harten, "High Resolution Schemes for Hyperbolic Conservation Laws,” Journal Computational Physics, Vol. 49, No. 3, 1983, pp. 357-393. doi:10.1016/0021-9991(83)90136-5

[19] C. A. J. Fletcher, "Computational Techniques for Fluid Dynamics, Vol. 1: Fundamental and General Techniques,” Springer-Verlag, Berlin/New York, 1988.

[20] L. H. Kanta and C. A. Clayson, "Numerical Models of Ocean and Ocean Processes," International geophysics series, Vol. 66, Academic Press, California, 2000.

[21] L. C. Walstra, L. C. Van Rijn, H. Blogg and M. Van Ormondt, "Evaluation of a Hydrodynamic Area Model 
Based on the COAST3D Data at Teignmouth 1999, Report TR121-EC MAST Project No MAS3-CT97-0086," HR Wallinford, UK, 2001, pp. D4.1-D4.4.

[22] W. M. Cameron and D. Pritchard, "Estuaries,” In: M. N. Hill, Ed., The Sea, Vol II, John Wiley and Sons, New York, 1963.

[23] O. O. Möller and P. Castaing, "Hydrographical Characteristics of the Estuarine Area of Patos Lagoon $\left(30^{\circ} \mathrm{S}\right.$, Brazil),” In: G. M. Perillo, M. C. Piccolo and M. Pino, Eds., Estuaries of South America: Their Geomorphology and Dynamics, Springer Verlag, Berlin, 1999.

[24] R. M. Castelão and O. O. Möller, “A Modeling Study of Patos Lagoon (Brazil) Flow Response to Idealized Wind and River Discharge: Dynamical Analysis,” Brazilian Journal of Oceanography, Vol. 54, No. 1, 2006, pp. 1-17.
[25] R. W. Garvine, “A Simple Model of Estuarine Subtidal Fluctuations Forced by Local and Non Local Remote Wind Stress,” Journal of Geophysical Research, Vol. 90, No. C6, 1985, pp. 11945-11948. doi:10.1029/JC090iC06p11945

[26] R. W. Garvine, "Subtidal Frequency Estuary-Shelf Interaction: Observartions near Delaware Bay," Journal of Geophysical Research, Vol. 96, No. C4, 1991, pp. 70497066. doi:10.1029/91JC00079

[27] W. C. Marques, E. H. Fernandes, I. O. Monteiro and O. O. Möller, "Numerical Modeling Numerical Modeling of the Patos Lagoon Coastal Plume, Brazil," Continental Shelf Research (2008), Vol. 29, No. 3, 2009, pp. 556-571. doi:10.1016/j.csr.2008.09.022 